\title{
Seasonal timing and duration of brachyuran larvae in a high-latitude fjord
}

\author{
Jennifer L. Fisher* \\ Moss Landing Marine Laboratories, 8272 Moss Landing Road, Moss Landing, California 95039, USA \\ Present address: Bodega Marine Laboratory, University of California at Davis, PO Box 247, Bodega Bay, \\ California 94923, USA
}

\begin{abstract}
The present study describes the seasonal distribution and abundance of brachyuran crab larvae from 5 families in lower Glacier Bay (SE Alaska, USA), and is one of the few field studies describing the entire pelagic phase of brachyuran larvae in Alaska. The larvae of most brachyuran species in Glacier Bay exhibited a highly seasonal pattern of abundance, which when first observed coincided with the onset of oceanographic conditions favorable to survival (high water temperature and abundant food supply). During May, larval abundance of Cancer magister increased by $63 \%$ relative to the first sampling date, that of $C$. oregonensis by $92 \%$, Fabia subquadrata by $69 \%$, Pugettia spp. by $73 \%$, and Majidae by $77 \%$. The seasonal timing and larval duration of C. magister and 4 other species in Glacier Bay were compared with the same species at lower latitudes to substantiate the hypothesis that larval release time and duration are later and longer, respectively, with increasing latitude. The initial occurrence of zoeae is delayed by 3 to 4 mo relative to published release times in California, Oregon and Washington for these species. Further, the pelagic larval duration for C. magister is approximately $30 \mathrm{~d}$ longer in SE Alaska than published larval durations in lower latitudes, suggesting that both these phenomena are a function of the cool water temperatures found in the former region.
\end{abstract}

KEY WORDS: Larval duration · Timing · High latitude · Cancer magister • Cancer oregonensis • Larvae · Fjord Resale or republication not permitted without written consent of the publisher

\section{INTRODUCTION}

Like many adult marine invertebrates with limited ranges of movement, brachyurans exhibit broadcast reproductive strategies that constitute the majority of their dispersal phase. After brooding eggs beneath their abdomen, they release planktotrophic larvae that spend months in the plankton before metamorphosing and settling to the bottom as juveniles. Most studies of population dynamics, recruitment patterns and settlement timing of brachyuran larvae in the NE Pacific have focused on the commercially important species Cancer magister from California (Reilly 1983), Oregon (Lough 1974), Washington (Stevens \& Armstrong 1984) and British Columbia (Jamieson \& Phillips 1988, 1993, Jamieson et al. 1989, Jamieson \& Armstrong 1991, McConnaughey et al. 1992, Dinnel et al. 1993). Studies conducted on the pelagic larval phase of C. magister suggest that the timing of larval release and the pelagic larval duration generally vary with latitude. Along the outer coast of California, Oregon and Washington, larval timing and duration are similar; larvae occur in the plankton from mid-January to May/June, translating to a larval duration of approximately $120 \mathrm{~d}$. In the Georgia, Haro and Rosario Strait complex (GHRS) of British Columbia, larvae are most abundant in the plankton from March to August, translating to a larval duration of approximately 150 d (Jamieson \& Phillips 1988). As C. magister larvae develop along the outer coast, there is a shift in larval abundance with distance from shore. Early stage larvae are found in close proximity to the coastline, while late stage larvae have been found up to 200 km offshore (Lough 1976, Reilly 1983, Jamieson \& Phillips 1988). In the GHRS, C. magister megalopae are 
retained by vertical migration from outward-flowing shallow water into deep inward-flowing bottom currents during the day, resulting in little to no exchange of megalopae to outer coastal areas (Jamieson \& Phillips 1993). Jamieson \& Phillips (1993) partly attributed the longer development time of larvae in the GHRS to the extreme temperature fluctuations encountered during these vertical migrations.

Few studies have been conducted on the temporal distribution of decapod larvae in Alaska (Incze et al. 1987, Park \& Shirley 2005), despite the commercial importance of many species in this area, including the Dungeness crab Cancer magister, the red king crab Paralithodes camtschatica and the Tanner crab Chionoecetes bairdi. No studies have been conducted on non-commercially important species. From monthly samples, Park \& Shirley (2005) reported the seasonal timing of 3 cancrid species in SE Alaska for part of their pelagic larval duration (4 mo), but no study has documented the entire pelagic phase.

Estimates of larval duration in nature have been inferred from laboratory studies and/or field studies with coarse temporal resolution; however, these approaches have inherent problems with accuracy and precision, respectively. Laboratory estimates of larval duration are known to be shorter, on average, than estimates based on field observations (Lough 1976, Reilly 1983, Sulkin \& McKeen 1994), presumably because larvae reared in the laboratory experience conditions more favorable to survival (e.g. absence of predators, increased temperature and supplemented food resources). Field studies of larval duration in the NE Pacific have been made at sampling intervals of $\sim 1$ mo (Lough 1976, Reilly 1983, Park \& Shirley 2005), resulting in an uncertainty of ca. $\pm 30 \mathrm{~d}$. To accurately and precisely estimate the time that larvae are in the water column, and to estimate the time needed for individual larval stages to develop, field sampling with a temporal resolution finer than 1 mo is necessary.

From plankton samples collected weekly, the present study describes the temporal distribution and abundance of brachyuran larvae in lower Glacier Bay, a high-latitude fjord in SE Alaska. This is one of the few field studies describing the entire pelagic phase of brachyuran larvae in Alaska (see Incze et al. 1987 for Chionoecetes bairdi and C. opilio), and the only study with a temporal resolution of $<1$ mo. Furthermore, the seasonal timing and larval duration of Cancer magister (because of the commercial importance and previous studies conducted on this species) and 4 other species observed in Glacier Bay were compared to those of the same species at lower latitudes, to substantiate the hypothesis that the timing of larval release and larval duration of brachyuran crabs are later and longer, respectively, with increasing latitude.

\section{MATERIALS AND METHODS}

Study site. Glacier Bay is a rapidly de-glaciating fjord in SE Alaska, approximately $100 \mathrm{~km}$ long from the entrance sill (30 $\mathrm{m}$ depth) to its northern reaches, and varying in width from approximately 15 to $4 \mathrm{~km}$ at its narrowest point in Sitakaday Narrows (Fig. 1). There is significant freshwater input, mainly from runoff and glacial meltwater in the upper bay, which contributes to a net down-bay flow of water. The mixed semi-diurnal average tidal range is approximately $3.7 \mathrm{~m}$ at Bartlett Cove in the lower bay and $4.2 \mathrm{~m}$ in upper bay locations. Oceanographic research in Glacier Bay by the United States Geological Survey (USGS) from 1993 to 2002 has shown that Glacier Bay sustains high primary productivity (chlorophyll a levels) from May to October (Fig. 2) (Etherington et al. 2004).

Plankton sampling. Plankton samples were collected approximately weekly during the day $(\mathrm{n}=22$ sampling days) using discrete depth and surface tows from a $9.6 \mathrm{~m}$ vessel from April 26 to October 5, 2002. Discrete depth tows were conducted using a General Oceanics double-trip opening and closing mechanism with $0.5 \mathrm{~m}$ diameter ring nets fitted with $500 \mu \mathrm{m}$ mesh

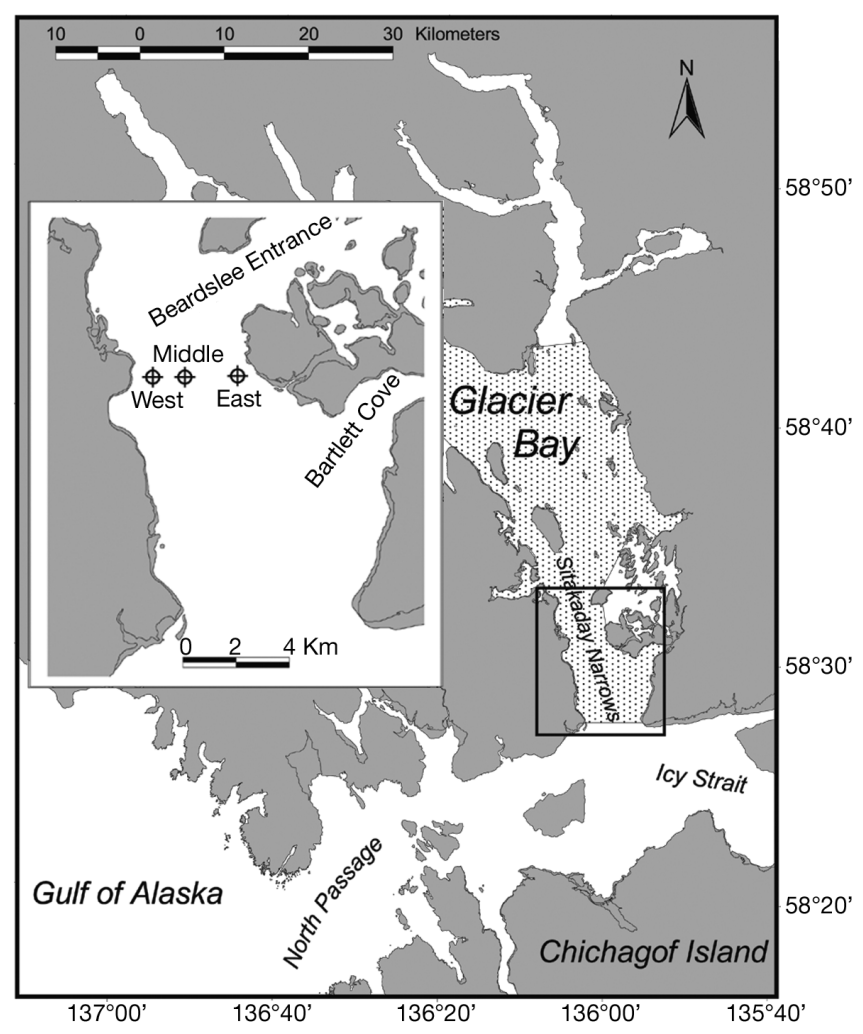

Fig. 1. Study area and sampling sites $(\phi)$ in Sitakaday Narrows, SE Alaska, USA. The entire bay is closed to commercial harvesting of Cancer magister and Paralithodes camtschaticus; stippled area depicts that part of the bay open to commercial harvesting of Chionoecetes bairdi 


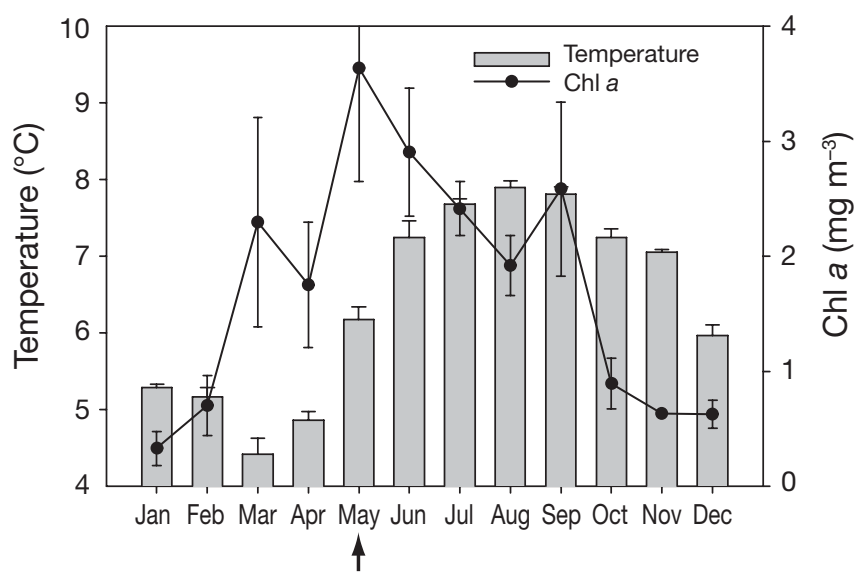

Fig. 2. Mean $( \pm \mathrm{SE})$ seasonal patterns of temperature and chlorophyll a in Sitakaday Narrows from 1993 to 2002 (combined data) averaged over the entire water column (data from USGS Glacier Bay Field Station, Gustavus, AK). Arrow indicates average larval release time for many species observed during the present study

netting modified with a choke band. Each net had a time-depth recording device to determine whether the net sampled the intended depth. Surface tows were conducted with a 0.5 by $0.75 \mathrm{~m}$ neuston net fitted with $500 \mu \mathrm{m}$ mesh. Each net was equipped with a General Oceanics flowmeter (Model 2030) so that the volume of water sampled could be calculated. All nets were towed at approximately 2 knots (relative to water current speed), against the prevailing current. The discrete depth and surface nets were towed for approximately 12 and $8 \mathrm{~min}$, respectively (sampling time was reduced for surface tows to minimize clogging of the net with phytoplankton), resulting in an average water volume sampled of $186 \mathrm{~m}^{3}$ (SD $72 \mathrm{~m}^{3}$ ) for tows at depth and $132 \mathrm{~m}^{3}$ (SD $51 \mathrm{~m}^{3}$ ) for surface tows.

Within each tide cycle (ebb and flood), 3 sites were sampled in Sitakaday Narrows (west, middle, east) (Fig. 1). These sites were located in water of approximately $50 \mathrm{~m}$ depth and were systematically chosen to represent a spatial distribution across the Narrows. I sampled 3 discrete depths at each site, resulting in a total of 18 samples per sampling outing and 395 samples in all. Depths were initially chosen systematically to represent areas of potential vertical flow differences such as benthic boundary layers and areas of potential water stratification (surface, midwater and bottom). Due to logistical constraints (e.g. small vessel size, limited net retrieval system and strong current speeds encountered in the Narrows), the greatest depth that could be consistently sampled was $30 \mathrm{~m}$, which was not influenced by the benthic boundary layer. Therefore, the surface, midwater and bottom tows were located at water depths of $0.5,10$, and $30 \mathrm{~m}$, respectively. All depths, sites and tides were averaged for ease of presentation (see Fisher 2005 for information on horizontal and vertical distributions and ebb/flood differences).

Sample processing. Each sample was preserved in a buffered $4 \%$ formalin solution in seawater. Based on the abundance of larvae and zooplankton present, samples were split using a Folsom plankton splitter in the laboratory, and all densities were standardized to a constant volume (no. of larvae $100 \mathrm{~m}^{-3}$ ). The presence or absence and relative abundance of zooplankton and anomuran larvae was qualitatively noted. All brachyuran larvae were picked out by hand using a dissecting microscope $(10 \times$ to $40 \times)$ and identified to stage and species whenever possible using a variety of larval keys (Hart 1935, 1960, Knudsen 1959, Kurata 1963, Poole 1966, Trask 1969, Lough 1974, Ally 1975, Haynes 1981, Iwata \& Konishi 1981, Debrosse et al. 1990a,b). If larvae could not be identified to species, they were identified to genus or family.

Within the family Majidae, 3 species (Hyas lyratus, Oregonia gracilis and Chionoecetes bairdi) have zoeal stages that are difficult to separate morphologically; therefore, these zoeae were treated collectively as Majidae. Megalopae of C. bairdi were conspicuous and easily distinguishable by numerous carapace and rostral spines, and $H$. lyratus and $O$. gracilis megalopae were distinguishable by the presence or absence of lateral carapace spines. However, these lateral carapace spines are easily damaged and could have been missed during identification. Therefore, H. lyratus and O. gracilis megalopae were pooled. The species grouping Pugettia spp. possibly included both $P$. gracilis and $P$. producta, because it was difficult to separate these species using external morphological features. Nevertheless, it was likely that the larvae observed were $P$. gracilis, since P. gracilis adults have been observed in Glacier Bay and P. producta adults have not. The published northern limit of $P$. producta is Prince of Wales Island, Alaska, $600 \mathrm{~km}$ to the south, but this species has been observed off Chichagof Island, $20 \mathrm{~km}$ to the south of Glacier Bay (O'Clair \& O'Clair 1998, Donnellan, National Park Service, pers obs.). Pinnixa spp. was most probably $P$. littoralis or $P$. occidentalis. $P$. littoralis is generally found as a symbiont in bivalves, which are abundant in Glacier Bay, but its presence in the bay would be beyond the published northern range of Sitka, Alaska. However, P. occidentalis inhabits the spoonworm Echiurus echiurus alaskanus, which is widely distributed throughout Glacier Bay (Sharman et al. 2003).

Larval duration. For comparison with previous studies, larval duration was recorded in 2 ways: development time for the zoeal stages and development time for the entire pelagic phase (from larval release through the megalopal stage). The development time for the zoeal stages was recorded as the time from 
which the Stage I zoeae were first observed in the plankton to the time that the megalopae were first observed. Larval development time for the entire pelagic phase was recorded as the average time between the minimum and maximum duration, with the minimum duration equal to the development time for the zoeal stages, and the maximum duration comprising the time from which Stage I zoeae were first observed in the plankton to the time that the last megalopa was observed. Reilly (1983) defined larval duration for the entire pelagic phase as the period from the first collection of Stage I zoeae to the time postlarvae were first collected from the benthos. I assumed Reilly's (1983) estimate of development time to be longer than my estimate for the entire pelagic phase, since I did not monitor the time to metamorphosis and settlement of postlarvae to the benthos. Lough (1974) apparently estimated larval duration as the time from the peak occurrence of Stage I zoeae to the time that megalopae were generally absent from the plankton, which was comparable to my estimate for the entire pelagic phase. Both Lough (1974) and Reilly (1983) sampled at approximately monthly intervals, resulting in an approximate uncertainty of $\pm 30 \mathrm{~d}$.

\section{RESULTS}

\section{Species abundance and temporal distribution}

In 395 plankton samples, larval stages of 12 species were observed, representing 5 families of brachyuran crabs (Table 1). Of these, 6 species/species groups were abundant enough for analysis, and they exhibited a strong seasonal pattern in larval abundance, with a rapid increase of first stage zoeae occurring in May (Figs. 3 to 5). For these species, the peak abundances of subsequent zoeal stages occurred sequentially and diminished over time, and the megalopae of most species were largely absent from the plankton at the end of the sampling season in early October (Figs. 3 to 5).

With the exception of Telmessus cheiragonus and the Majidae group, Stage I zoeae of most species were present in the plankton for approximately 12 to $16 \mathrm{wk}$. This protracted period that Stage I larvae were in the water column, coupled with multiple peaks of Stage I zoeae of Cancer magister, indicated nonsynchronous release and/or the possibility of

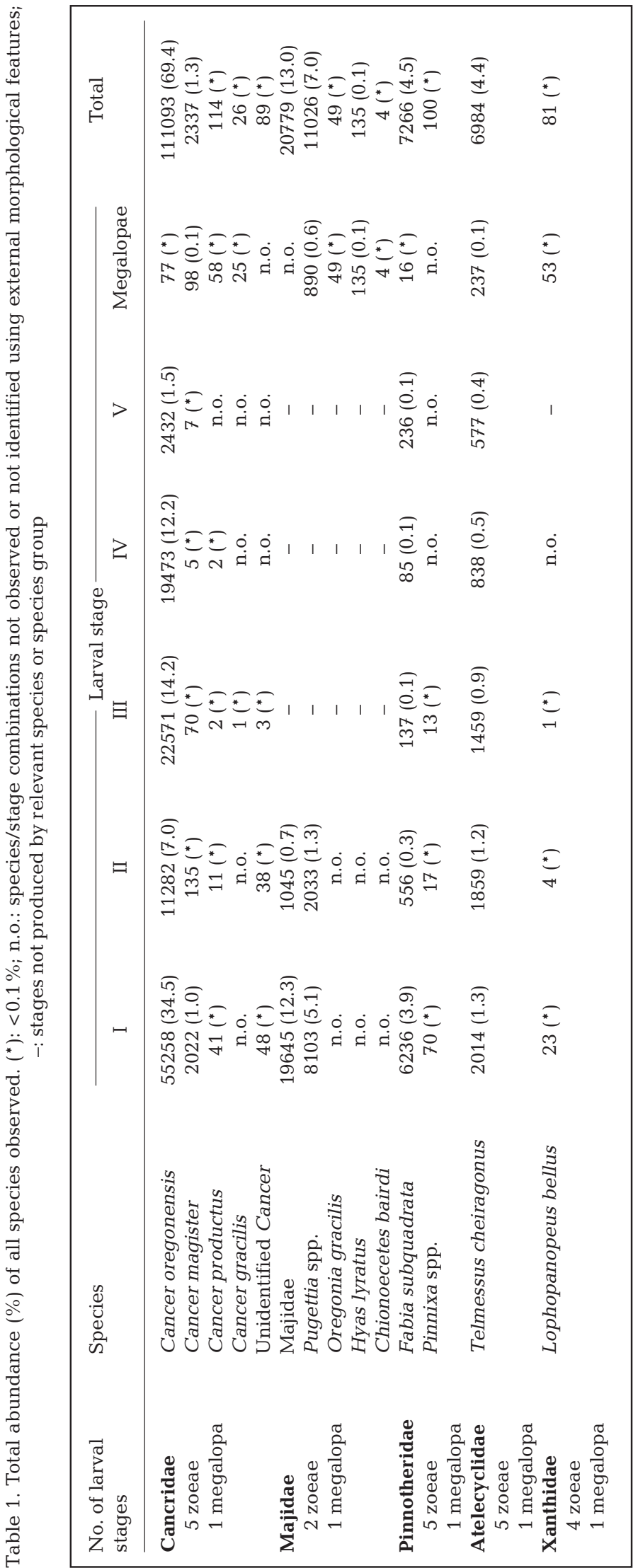




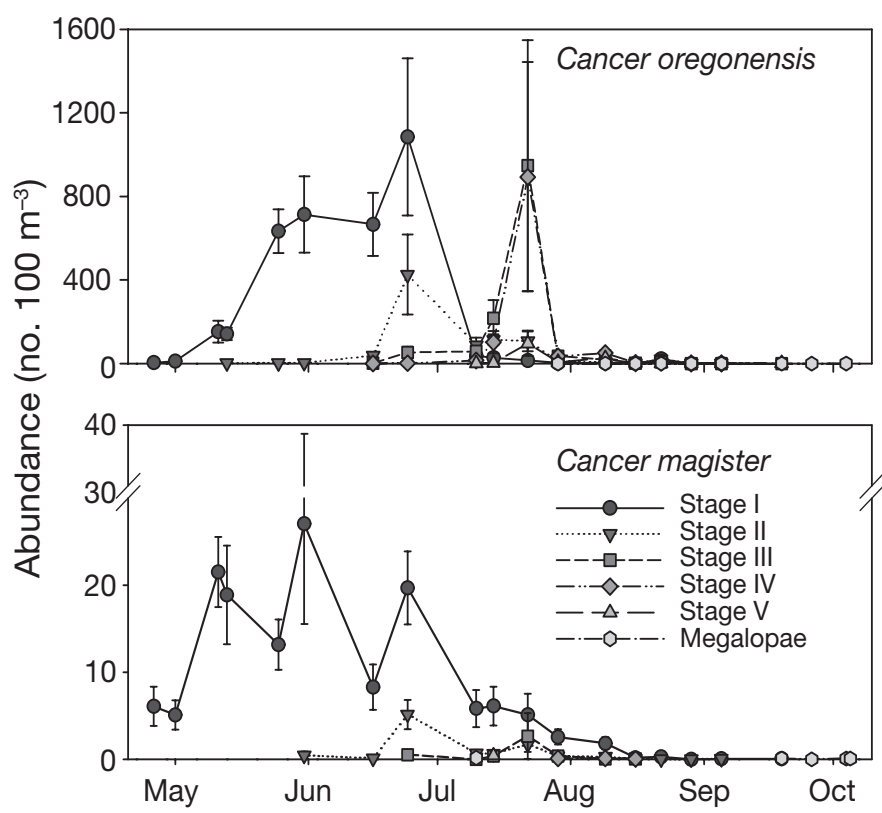

Fig. 3. Cancer oregonensis and C. magister. Mean $( \pm \mathrm{SE})$ larval abundance throughout the study period from April 26 to October 5, 2002. Data averaged for all sites, depths and tides sampled

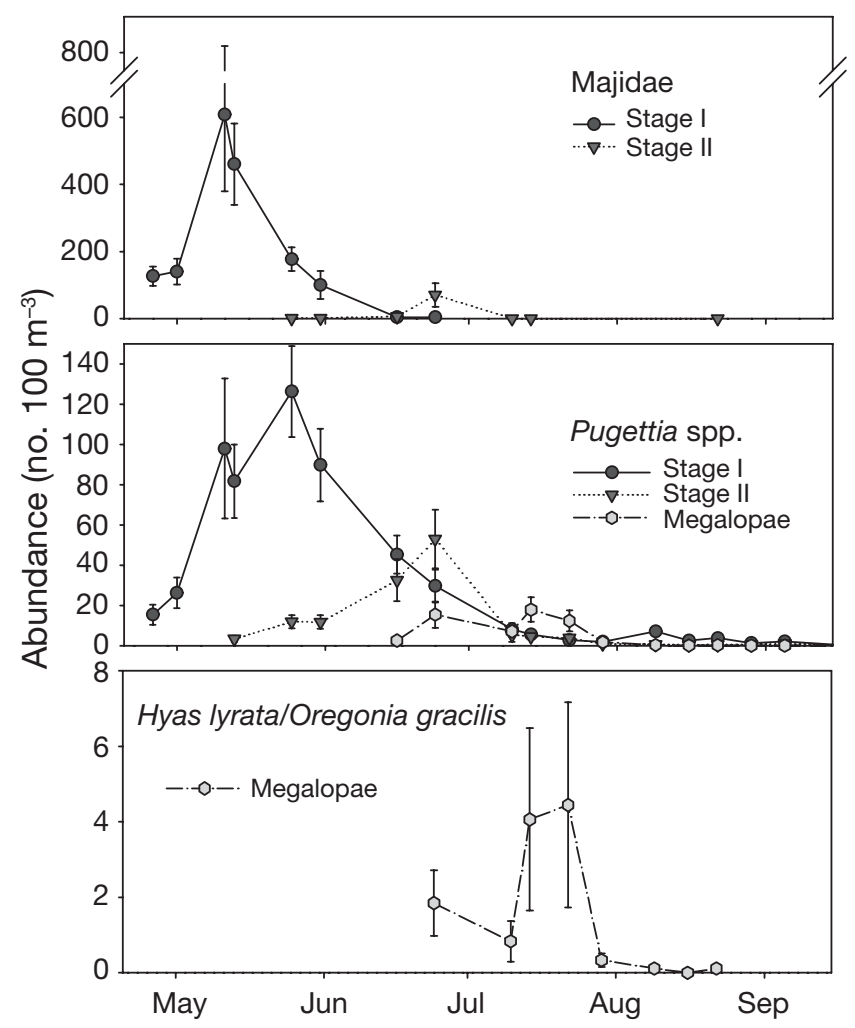

Fig. 4. Majidae (Chionoecetes bairdi, Hyas lyratus, Oregonia gracilis), Pugettia spp., and $H$. lyratus/O. gracilis. Mean $( \pm \mathrm{SE})$ larval abundance throughout the study period from April 26 to October 5, 2002. Data averaged for all sites, depths and tides sampled

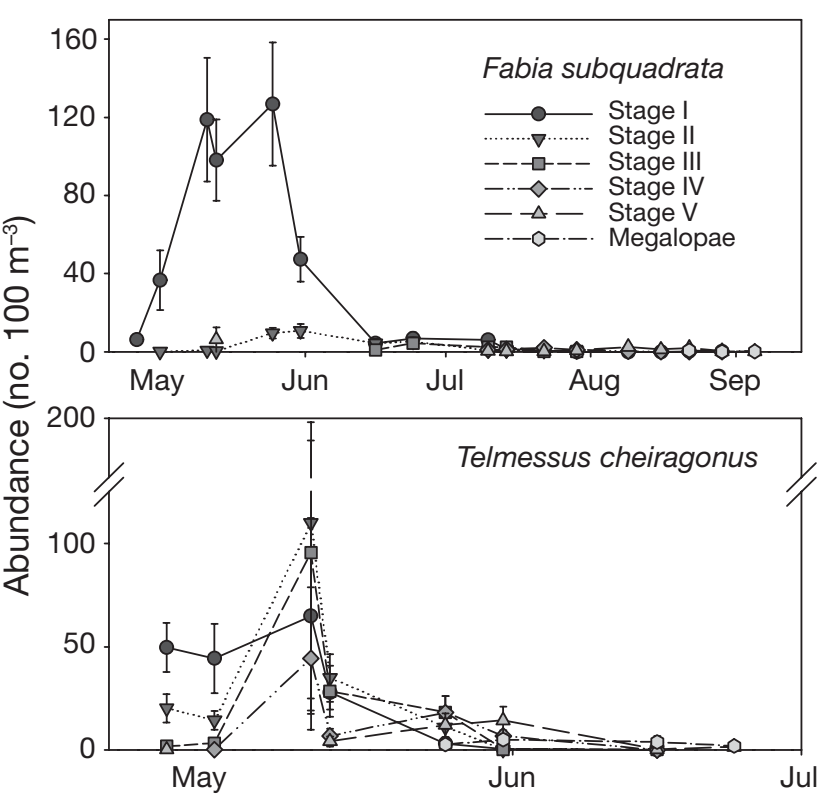

Fig. 5. Fabia subquadrata and Telmessus cheiragonus. Mean $( \pm$ SE) larval abundance throughout the study period from April 26 to October 5, 2002. Data are averaged for all sites, depths and tides sampled

multiple cohorts. T. cheiragonus and the group Majidae Stage I zoeae were already present in the plankton in relatively large numbers at the onset of sampling, so the minimum estimated time that first stage larvae were present in the plankton was approximately $4 \mathrm{wk}$.

\section{Family Cancridae}

Cancer oregonensis were the most abundant larvae observed, comprising $69 \%$ of the total (Table 1). Abundance peaked on June 24 with a mean density of 1085 Stage I zoeae $100 \mathrm{~m}^{-3}$ and a maximum density of 5218 zoeae $100 \mathrm{~m}^{-3}$ (Fig. 3). Although the total abundance of subsequent zoeal stages was substantially lower, on July 22 the densities of Stage III and IV zoeae were similar to the maximum density observed for Stage I zoeae, indicating a possible influx of these stages from outlying areas. Megalopae were first collected on July 29, and occurred at low densities until October 4.

Three peaks in the density of Stage I Cancer magister zoeae were observed on May 11 and 31 and June 24, and 2 peaks in Zoeae Stage II on June 24 and August 22, although densities were low $\left(<10\right.$ per $\left.100 \mathrm{~m}^{3}\right)$, and Stage III to V zoeae were rare $\left(<3\right.$ per $\left.100 \mathrm{~m}^{3}\right)$ throughout the sampling period (Fig. 3). A single megalopa was collected on July 10, but most were collected from September 19 until sampling ended on October 5.

Zoeal stages of Cancer productus were collected in low numbers, and no Stage V zoeae were observed 
(Table 1). Stage II zoeae were collected prior to Stage I, indicating that the larval hatching period was earlier than the first observation of Stage I zoeae on July 29. Furthermore, abundance of Stage I zoeae in October was similar to that in July, suggesting that the larval hatching period for C. productus may be more protracted than for the other species. Megalopae peaked in abundance over 3 subsequent dates: September 29 and October 4 and 5. C. gracilis were the least abundant larvae collected, with only 1 Stage III zoea observed (Table 1).

\section{Family Majidae}

The Stage I zoeae of the majids Oregonia gracilis, Hyas lyratus and Chionoecetes bairdi were second highest in abundance (Table 1). This may have been attributable, in part, to combining the 3 distinct species. However, even if each species was represented equally ( $\sim 4 \%$ of total larvae observed), they would comprise the third most abundant, with Pugettia spp. as second (5.1\% of total larvae observed). At least 1 larval stage from the genus Pugettia was observed on almost every sampling date. Peak abundance occurred later with each subsequent larval stage of this species, indicating that a single cohort was being followed throughout the sampling season (Fig. 4). Megalopae of O. gracilis and $H$. lyratus were collected from June 24 through August 22 in moderate numbers, and peaked on July 22 with 47 megalopae $100 \mathrm{~m}^{-3}$ collected on the surface at one site (Fig. 4). C. bairdi zoeae were not distinguished, and megalopae were very rare; only 3 individuals were collected (August 22 and 29 and October 6).

\section{Family Pinnotheridae}

Abundance of Fabia subquadrata Stage I zoeae peaked on May 25 and then declined precipitously. Stage II to V zoeae were never collected at densities greater than 10 zoeae $100 \mathrm{~m}^{-3}$. Megalopae were collected from July 29 until October 4, but never in great numbers (16 total over the entire sampling period) (Fig. 5). A total of 100 zoeae of Pinnixa spp. were collected throughout the sampling period (Table 1), $70 \%$ of which were Stage I zoeae. Stage IV and V zoeae and megalopae were not collected.

\section{Family Atelecyclidae}

Stage I to IV zoeae of Telmessus cheiragonus peaked in abundance on May 11, indicating that hatching had occurred considerably earlier than the onset of sampling (Fig. 5). Megalopae were collected continuously in low numbers (<6 megalopae $100 \mathrm{~m}^{-3}$ ) from May 13 to June 24 .

\section{Family Xanthidae}

Lophopanopeus bellus larvae were collected at low densities throughout the study (Table 1). Stage I zoeae were collected during every sampling event from May 31 through August 22, and Stage II and III zoeae were collected occasionally throughout August. Megalopae were observed on May 25 and again in September and October. The occurrence of megalopae on 2 separate dates indicates that this species released 2 broods spaced seasonally in the spring and fall, which has also been documented in Puget Sound (O'Clair \& O'Clair 1998).

\section{Larval duration}

Larval duration was estimated for the most abundant species and is summarized in Table 2. For most species, first stage larvae (Stage I zoeae) were already present in the plankton at the onset of sampling; therefore, the pelagic phase was not sampled in its entirety. Thus, estimates of larval duration underestimate the actual time it takes for development from hatching to settlement in this region. However, the rapid increase in zoeal abundance following the onset of sampling indicates that sampling was close to the initial release of larvae. The low densities of Cancer gracilis and Lophopanopeus bellus zoeae and Chionoecetes bairdi megalopae precluded an accurate estimate of larval duration for those species. Cancer magister, C. oregonensis, Fabia subquadrata, and Pugettia spp. had the longest larval durations, spanning the entire length of the study (approximately 119 to $154 \mathrm{~d}$ ).

\section{DISCUSSION}

During May, zoeal abundance of Cancer magister increased by $63 \%$ relative to the first sampling date, Fabia subquadrata by $69 \%$, Pugettia spp. by $73 \%$, Majidae by $77 \%$ and C. oregonensis by $92 \%$. This first peak of Stage I zoeae is approximately 3 to 4 mo later than the times reported by Lough (1976) for C. magister, C. oregonensis, and F. subquadrata in central Oregon. However, the timing of $C$. magister and Chionoecetes bairdi is comparable to that in studies conducted in Canada and the Bering Sea (Incze et al. 1987) (Table 2).

Larval release is generally triggered by physical and/or biological cues such as tidal fluctuations and 
Table 2. Seasonal timing of Stage I zoeae ('First occurrence') and mean (minimum-maximum) larval duration recorded in the present study and in published studies from other geographic regions. * : larval durations estimated from published opportunistic observations of Stage I zoeae and megalopae in the field

\begin{tabular}{|c|c|c|c|c|}
\hline Region & $\begin{array}{c}\text { First } \\
\text { occurrence }\end{array}$ & \multicolumn{2}{|c|}{ Development time (d) } & Source \\
\hline \multicolumn{5}{|l|}{ Cancer magister } \\
\hline SE Alaska & Apr 26 & 146 & $154(146-162)$ & This study \\
\hline Inside waters, Wash & Mar-Apr & & $150^{*}$ & $\begin{array}{l}\text { Orensanz \& Gallucci (1988) Jamieson \& } \\
\text { Phillips (1993) Armstrong et al. (1987) }\end{array}$ \\
\hline Outer coast, Wash & Jan-Feb & & $120^{*}$ & Dinnel et al. (1993) \\
\hline Central Oregon & Jan 29 & $105(94-130)$ & $130(89-143)$ & Lough (1976) \\
\hline Central Calif & Dec 12 & $80-95$ & $115(105-125)$ & Reilly (1983) \\
\hline Lab $10^{\circ} \mathrm{C}$ (N Calif) & & 69 & & Sulkin \& McKeen (1994) \\
\hline \multicolumn{5}{|l|}{ Cancer oregonensis } \\
\hline SE Alaska & Apr 26 & 94 & $133(105-161)$ & This study \\
\hline Central Oregon & Jan & & $120(105-140)$ & Lough (1976) \\
\hline Lab $10^{\circ} \mathrm{C}$ (N Calif) & & 72 & & Sulkin \& McKeen (1994) \\
\hline \multicolumn{5}{|l|}{ Cancer productus } \\
\hline SE Alaska & Jul 14 & 74 & 83 & This study \\
\hline Puget Sound & Mar-Jun & & & O'Clair \& O'Clair (1998) \\
\hline Lab $11^{\circ} \mathrm{C}$ (N Calif) & & 97 & & Trask (1969) \\
\hline Lab $10^{\circ} \mathrm{C}$ (N Calif) & & 59 & & Sulkin \& McKeen (1994) \\
\hline \multicolumn{5}{|l|}{ Fabia subquadrata } \\
\hline SE Alaska & Apr 26 & 118 & $125(118-132)$ & This study \\
\hline Central Oregon & Feb & & $90(63-200)$ & Lough (1976) \\
\hline Lab $11-13^{\circ} \mathrm{C}$ (Wash) & & & 54 & Irvine \& Coffin (1960) \\
\hline \multicolumn{5}{|l|}{ Pugettia spp. } \\
\hline SE Alaska & Apr 26 & 51 & $121(79-163)$ & This study \\
\hline Central Oregon & All year & & $49(45-53)$ & Lough (1976) \\
\hline \multicolumn{5}{|l|}{ Majidae zoeae } \\
\hline SE Alaska & Apr 26 & 59 & $103(87-118)$ & This study \\
\hline \multicolumn{5}{|l|}{ C. bairdi zoeae } \\
\hline Bering Sea & Apr-Jun & & & Incze et al. (1987) \\
\hline \multicolumn{5}{|c|}{ Hyas lyratus/Oregonia gracilis megalopae } \\
\hline SE Alaska & & & 31 & This study \\
\hline \multicolumn{5}{|l|}{ Telmessus cheiragonus } \\
\hline SE Alaska & Apr 26 & 29 & $47(35-59)$ & This study \\
\hline
\end{tabular}

light/dark regimes (see Morgan 1995 for review), temperature increases (Shirley \& Shirley 1989), phytoplankton blooms (Starr et al. 1990), or a combination of any of the above. In high latitude regions, crabs are subjected to dramatic seasonal fluctuations and environmental forces. In Glacier Bay, tidal changes are great ( $\sim 4 \mathrm{~m}$ daily, on average), and seasonal variations in temperature, salinity and light/dark regimes are dramatic. The larvae of most brachyuran species observed in Glacier Bay exhibited a highly seasonal pattern of abundance, which when first observed coincided with the onset of oceanographic conditions favorable to survival (increasing water temperature and abundant food supply). Zoeal abundance increased dramatically in May, concurrent with an increase in water temperature of almost $2^{\circ} \mathrm{C}$ (from $4.4^{\circ} \mathrm{C}$ in March to $6.2^{\circ} \mathrm{C}$ in May) and the seasonal peak in chlorophyll a values (Fig. 2). If larvae were released in Glacier Bay prior to May, the water temperature would have been approximately $5^{\circ} \mathrm{C}$. From model simulations based on known temperature tolerances of Cancer magister by Moloney et al. (1994), 100 \% larval mortality would occur at $5.1^{\circ} \mathrm{C}$. Further, their models predicted that larvae would have the highest rates of survival to metamorphosis when they were released during periods of rising temperature and when temperatures were warmest $\left(15^{\circ} \mathrm{C}\right)$.

While it is important that larvae are released during times of favorable water temperatures and abundant food resources, release time may also be a function of embryo development time. Shirley \& Shirley (1989) found that the embryo hatch time of Paralithodes camtschaticus was not correlated with the phytoplankton bloom in SE Alaska, but was instead dependent on embryo development time. The delayed hatching time of brachyuran larvae in Glacier Bay relative to many of the same species from field studies at lower latitudes (Lough 1976, Reilly 1983) may in part be explained by prolonged embryo development time. From laboratory studies, Shirley et al. (1987) found that the duration of 
Cancer magister embryo incubation was inversely proportional to water temperature. Indeed, during a year of cooler sea surface temperatures $\left(10.6^{\circ} \mathrm{C}\right)$, Reilly (1983) observed Stage I zoeae of C. magister in the plankton almost 1 mo later than during years of warmer temperatures (12.8 to $13.1^{\circ} \mathrm{C}$ ). In Glacier Bay, C. magister adults extrude eggs in September through November (Swiney \& Shirley 2001), which is identical to the reported extrusion period in California (Wild 1983). At $5^{\circ} \mathrm{C}$ and ambient temperatures of $12^{\circ} \mathrm{C}$ off Central California, embryo developmental time in the laboratory, from extrusion to hatch, was estimated at $160 \mathrm{~d}$ (Shirley et al. 1987) and $80 \mathrm{~d}$ (Wild 1983), respectively. With an average water temperature over this period in Glacier Bay of approximately $5^{\circ} \mathrm{C}$ (Fig. 2), the estimated earliest hatching period would occur in March through May. This estimate coincides with the timeframe when hatching did occur in 2002 (May to August), and most likely explains the delayed larval release time compared to release times at lower latitudes (December to January in central California), at least for C. magister.

The prolonged hatching period observed for some species indicates that there was no single bay-wide event that the adults tracked (e.g. temperature or chlorophyll) to release larvae. Long release times could either be sustained by high phytoplankton abundance, be the result of delayed development due to cool water temperatures during embryo incubation time, or be a strategy to ensure larval release during favorable oceanographic conditions for survival. Shirley et al. (1987) found that larval hatching duration was inversely proportional to water temperature. In his study, female Cancer magister reared at $5^{\circ} \mathrm{C}$ released larvae over a $25 \mathrm{~d}$ period. However, during the present study, Stage I zoeae of C. magister were observed in the plankton for $146 \mathrm{~d}$, indicating that factors other than water temperature were probably influencing larval hatching. Extended larval release time by the population could also be the result of multiple cohorts being released in a season, or the continual release of larvae. Once their embryos are developed, crabs may release larvae as long as temperatures permit larval survivorship. However, at some point it becomes disadvantageous to release larvae. Stage I C. magister zoeae released in August during this study would be estimated to settle in January when primary productivity, and thus food resources, are at their lowest, and water temperatures are approximately $5^{\circ} \mathrm{C}$. At this time of year, larval mortality would likely be $100 \%$ due to temperature effects alone (Moloney et al. 1994). Thus, larvae released this late would probably face very low survivorship to metamorphosis because of minimal food and critically low water temperatures.
For all species, the larval durations reported here are longer than those reported by Lough (1974). The larval duration of Cancer magister (Table 2) is longer than the durations reported for the outer coast of California to Washington, and comparable to durations of $C$. magister in the inside waters of Washington (Jamieson \& Phillips 1993). Environmental factors (e.g. temperature) have been suggested as determinants influencing larval duration times (Pechenik 1987). Overall, shorter larval durations minimize the time that larvae are susceptible to predation in the plankton. Temperature (Sulkin \& McKeen 1994) and increased food availability (Paulay et al. 1985) are inversely related to larval development time due to rapid growth under optimal conditions (abundant food and warm water). Therefore, the prolonged larval durations observed during this study, compared to field studies in lower latitudes, may be attributed to the cooler water temperatures experienced. Moloney et al. (1994) predicted that at $6.1^{\circ} \mathrm{C}$, the larval duration (from hatch to settlement) of C. magister would be $260 \mathrm{~d}$. Therefore, at an average temperature of $6.8^{\circ} \mathrm{C}$ from April 26 to October 17 (averaged over the entire water column [n $=5$ sampling periods, $\mathrm{SE} 0.05^{\circ} \mathrm{C}$ ] at an oceanographic sampling station near the study area, USGS data Glacier Bay Field Station), the estimated larval duration of $154 \mathrm{~d}$ for C. magister was much shorter than that predicted by Moloney et al. (1994), but comparable to observations by Jamieson \& Philips (1993) of C. magister larval durations in the inside waters of British Columbia. This apparent contradiction might be explained by high primary productivity in Glacier Bay, although it appears that food abundance alone did not compensate enough to reduce the larval duration time relative to that at lower latitudes.

To ensure viable offspring, it is imperative that adults couple larval hatching rhythms with times of favorable environmental conditions (Giese \& Pearse 1974). This could be especially problematic at high latitudes, where the window of favorable water temperatures and abundant food resources can be narrow. Further, decreased temperatures significantly increase larval duration (Shirley et al. 1987, Moloney et al. 1994, Sulkin \& McKeen 1994) which can increase vulnerability to mortality from predation. For a family such as the Cancridae, which has the longest known larval development time of all the brachyurans (Hines 1986), delayed larval hatching could mean the failure of an entire cohort. In contrast, premature larval hatching could have a large impact on overall survival to metamorphosis if larvae are released during unfavorable oceanographic conditions (cooler water temperatures and decreased food sources). In Glacier Bay, it is likely that multiple factors play a role in determining the timing and duration of larval release and overall larval 
development time. There appears to be a temperature threshold encompassing embryo development time that is coincident with favorable oceanographic conditions for larval release and subsequent development. Once this threshold is exceeded, it appears that release occurs until all larvae are released or until conditions become unfavorable for release. This window is short, and occurs during the summer months when water temperatures are at their maximum, and it is later than that for similar species at lower latitudes.

Acknowledgements. I thank J. Smith, E. Kean, and K. Wulff for tireless help in the field and while sorting samples, and M. Donnellan, S. Kim, S. Morgan, J. Geller, L. Sharman and 3 anonymous reviewers for contributions to the present manuscript. I also thank the staff at Glacier Bay National Park and Preserve for providing logistical support for this project. This work was supported by a National Park Service Challenge Cost Share Grant.

\section{LITERATURE CITED}

Ally R (1975) A description of the laboratory-reared larvae of Cancer gracilis Dana, 1852 (Decapoda, Brachyura). Crustaceana 28:231-246

Armstrong DA, Armstrong JL, Dinnel P (1987) Ecology and population dynamics of Dungeness crab, Cancer magister in Ship Harbor, Anacortes, Washington. Final report to Leeward Development Company and Washington State Department of Fisheries. FRI-UW-8701, Seattle, WA

Debrosse GA, Baldinger AJ, McLaughlin PA (1990a) A comparative-study of the megalopal stages of Cancer oregonensis Dana and Cancer productus Randall (Decapoda, Brachyura, Cancridae) from the Northeastern Pacific. Fish Bull (Wash DC) 88:39-49

Debrosse G, Sulkin S, Jamieson G (1990b) Intraspecific morphological variability in megalopae of three sympatric species of the genus Cancer (Brachyura, Cancridae). J Crustac Biol 10:315-329

Dinnel PA, Armstrong DA, McMillan RO (1993) Evidence for multiple recruitment-cohorts of Puget Sound Dungeness crab, Cancer magister. Mar Biol 115:53-63

Etherington L, Hooge P, Hooge E (2004) Factors affecting seasonal and regional patterns of surface water oceanographic properties within a fjord estuarine system: Glacier Bay, Alaska. USGS, Alaska Science Center, Anchorage, AK

Fisher J (2005) Larval dynamics of brachyuran crabs in a high latitude fjord, Southeast Alaska. Moss Landing Marine Laboratories, Moss Landing, CA

Giese A, Pearse J (1974) Reproduction of marine invertebrates. Academic Press, New York

Hart J (1935) The larval development of British Colombia Brachyura. I. Xanthidae, Pinnotheridae (in part) and Grapsidae. Can J Res 12:411-432

Hart J (1960) The larval development of British Colombia Brachyura. II. Majidae, subfamily Oregonidae. Can J Res 38:539-546

Haynes E (1981) Description of Stage-I zoeae of snow crab, Chionoecetes bairdi (Oxyrhyncha, Majidae), from plankton of lower Cook Inlet, Alaska. Fish Bull (Wash DC) 79: $177-182$
Hines A (1986) Larval patterns in the life histories of brachyuran crabs (Crustacea, Decapoda, Brachyura). Proceedings of the invertebrate larval biology workshop held at Friday Harbor Marine Laboratories. Bull Mar Sci 39(2):444-466

Incze L, Armstrong David A, Smith S (1987) Abundance of larval tanner crabs (Chionoecetes spp.) in relation to adult females and regional oceanography of the southeastern Bering Sea. Can J Fish Aquat Sci 44:1143-1156

Irvine J, Coffin HG (1960) Laboratory culture and early stages of Fabia subquadrata (Dana), (Crustacea, Decapoda). Walla Walla College Publications of the Department of Biological Sciences and the Biological Station 28:1-24

Iwata F, Konishi K (1981) Larval development in laboratory of Cancer amphioetus Rathburn, in comparison with those of seven other species of Cancer (Decapoda, Brachyura). Publ Seto Mar Biol Lab 27:369-391

Jamieson GS, Armstrong D (1991) Spatial and temporal recruitment patterns of Dungeness crab in the northeast Pacific. Mem Queensl Mus 31:365-381

Jamieson GS, Phillips AC (1988) Occurrence of Cancer crab (Cancer magister and Cancer oregonensis) megalopae off the west-coast of Vancouver Island, British-Columbia. Fish Bull (Wash DC) 86:525-542

Jamieson GS, Phillips A (1993) Megalopal spatial distribution and stock separation in Dungeness crab (Cancer magister). Can J Fish Aquat Sci 50:416-429

Jamieson GS, Phillips A, Huggett W (1989) Effects of ocean variability on the abundance of Dungeness crab (Cancer magister) megalopae. Can Spec Publ Fish Aquat Sci 108: 305-325

Knudsen J (1959) Life cycle studies of the Brachyura of Western North America. II. The life cycle of Lophopanopeus bellus diegenesis Rathburn. Bull South Calif Acad Sci 58: $57-65$

Kurata H (1963) Larvae of decapoda Crustacea of Hokkaido 1. Atelecyclidae (Atelecyclinae). Bull Hokkaido. Reg Fish Lab Board 27:13-24

Lough RG (1974) Dynamics of crab larvae (Anomura, Brachyura) off the central Oregon coast. PhD dissertation, Oregon State Univeristy, Corvallis, OR

Lough RG (1976) Larval dynamics of Dungeness crab, Cancer magister, off Central Oregon Coast, 1970-71. Fish Bull (Wash DC) 74:353-376

McConnaughey R, Armstrong D, Hickey B, Gunderson D (1992) Juvenile Dungeness crab (Cancer magister) recruitment variability and oceanic transport during the pelagic larval phase. Can J Fish Aquat Sci 49:2028-2044

Moloney CL, Botsford LW, Largier JL (1994) Development, survival and timing of metamorphosis of planktonic larvae in a variable environment: the Dungeness crab as an example. Mar Ecol Prog Ser 113:61-79

Morgan SG (1995) The timing of larval release, CRC Press, Boca Raton, FL

O'Clair RM, O'Clair CE (1998) Southeast Alaska's rocky shores: animals. Plant Press, Auke Bay, AK

Orensanz JM, Gallucci VF (1988) Comparative-study of postlarval life-history schedules in 4 sympatric species of Cancer (Decapoda, Brachyura, Cancridae). J Crustac Biol $8: 187-220$

Park W, Shirley TC (2005) Diel vertical migration and seasonal timing of the larvae of three sympatric cancrid crabs, Cancer spp., in southeastern Alaska. Estuaries 28:266-273

Paulay G, Boring L, Strathmann RR (1985) Food limited growth and development of larvae: experiments with natural seawater. J Exp Mar Biol Ecol 93:1-10

Pechenik J (1987) Environmental influences on larval survival and development. In: Giese A, Pearse J, Pearse V (eds) 
Reproduction of marine invertebrates, Vol 9. Boxwood Press, Palo Alto, CA

Poole R (1966) A description of laboratory-reared zoeae of Cancer magister Dana, and megalopae taken under natural conditions (Decapoda Brachyura). Crustaceana 11:83-97

Reilly PN (1983) Dynamics of Dungeness crab, Cancer magister, larvae off Central and Northern California. Calif Dep Fish Game Fish Bull 172:57-84

Sharman L, Eichenlaub B, Van Leeuwen D, Croll S, Grover J, Lenhart G, Hooge P (2003) NPS Alaska coastal resources inventory and mapping field protocol-the polygon method - developed at Glacier Bay National Park and Preserve 1997-1998. National Park Service, Glacier Bay National Park, Gustavus, AK

Shirley S, Shirley T (1989) Interannual variability in density, timing and survival of Alaskan red king crab Paralithodes camtschatica larvae. Mar Ecol Prog Ser 54:51-59

Shirley SM, Shirley TC, Rice SD (1987) Latitudinal variation in the Dungeness crab, Cancer magister, zoeal morphology explained by incubation temperature. Mar Biol 95: 371-376

Editorial responsibility: Howard I. Browman (Associate Editor-in-Chief), Storebø, Norway
Starr M, Himmelman J, Therriault J (1990) Direct coupling of marine invertebrate spawning with phytoplankton blooms. Science 247:1071-1074

Stevens B, Armstrong D (1984) Distribution, abundance and growth of juvenile Dungeness crabs, Cancer magister, in Grays Harbor estuary, Washington. Fish Bull (Wash DC) 82:469-483

Sulkin SD, McKeen G (1994) Influence of temperature on larval development of four co-occurring species of the brachyuran genus Cancer. Mar Biol 118:593-600

Swiney KM, Shirley TC (2001) Gonad development of southeastern Alaskan Dungeness crab, Cancer magister, under laboratory conditions. J Crustac Biol 21:897-904

Trask T (1969) A description of laboratory-reared larvae of Cancer productus Randall (Decapoda, Brachyura) and a comparison to larvae of Cancer magister Dana. Crustaceana 18:133-146

Wild PW (1983) The influence of seawater temperature on spawning, egg development, and hatching success of the Dungeness crab, Cancer magister. Calif Dep Fish Game Fish Bull 172:197-213

Submitted: January 26, 2006; Accepted: March 7, 2006

Proofs received from author(s): September 18, 2006 